$\begin{array}{ll}\text { Volume } & : 7 \\ \text { Nomor } & : \mathbf{3} \\ \text { Bulan } & : \text { Agustus } \\ \text { Tahun } & : \mathbf{2 0 2 1}\end{array}$
E-ISSH: 2656-940X 강 P-ISSI: 2442-367K (D) URL:jurnal.ideaspublishing.co.id

\title{
Pengaruh Efikasi Diri dan Motivasi Belajar terhadap Hasil Belajar Matematika Siswa Sekolah Dasar
}

\author{
Nurlatifah Rangkuti \\ Turmudi \\ Abdussakir \\ Universitas Islam Negeri Maulana Malik Ibrahim Malang \\ Pos-el: nurlatifahrangkuti@gmail.com
}

DOI: 10.32884/ideas.v7i3.415

\begin{abstract}
Abstrak
Penelitian ini bertujuan untuk menguji dan menganalisis pengaruh efikasi diri dan motivasi belajar terhadap hasil belajar matematika. Penelitian ini didesain dalam bentuk pendekatan Mixed Methods yang mengkombinasikan analisis kuantitatif dan kualitatif (Sequantial Explanatory). Teknik analisis data yang digunakan adalah analisis regresi berganda menggunakan SPSS Versi 23,0. Hasil penelitian ini menunjukkan bahwa terdapat pengaruh efikasi diri dan motivasi belajar yang signifikan positif terhadap hasil belajar matematika.
\end{abstract}

\section{Kata Kunci:}

efikasi diri, motivasi belajar, hasil belajar matematika

\begin{abstract}
This study aims to examine and analyze the effect of self-efficacy and learning motivation on mathematics learning outcomes. This research is designed in the form of a Mixed Methods approach that combines quantitative and qualitative analysis (Sequantial Explanatory). The data analysis technique used is multiple regression analysis using SPSS Version 23.0. The results of this study indicate that there is a significant positive effect of self-efficacy and learning motivation on mathematics learning outcomes.
\end{abstract}

Keywords:

self-efficacy, learning motivation, results learning math

\section{Pendahuluan}

Salah satu mata pelajaran yang disampaikan di jenjang sekolah dasar sampai perguruan tinggi adalah matematika. "Matematika merupakan salah satu disiplin ilmu yang dapat meningkatkan kemampuan berfikir dan berargumentasi, memberikan kontribusi dalam penyelesaian sehari-hari dan dalam dunia kerja, serta memberikan dukungan dalam pengembangan ilmu pengetahuan dan teknologi” (Ahmad, 2013). Bersumber pada uraian tersebut, pengaplikasian matematika sangat dibutuhkan dalam kehidupan sehari-hari dan dalam dunia kerja, dan menunjang dalam pertumbuhan ilmu pengetahuan sehingga matematika butuh dipahami dengan baik oleh siswa paling utama semenjak jenjang sekolah dasar.

Berdasarkan fakta yang peneliti dapatkan bahwa terlihat masih belum seluruhnya siswa mencapai nilai KKM dan masih rendahnya hasil belajar matematika siswa, yang dipengaruhi beberapa faktor dan beberapa siswa yang kurang percaya diri untuk memperoleh nilai ulangan yang maksimal. Berdasarkan hasil observasi ditemukan Permasalahan bahwa siswa belum seluruhnya memiliki percaya diri yang tinggi, dalam penyelesaian tugas-tugas sekolah, siswa kurang percaya terhadap kemampuannya sehingga siswa melihat hasil pekerjaan temannya. Adapun siswa yang kurang percaya diri berjumlah 15 siswa dari jumlah keseluruhan. Dan siswa yang kurang motivasi belajar ada 10 siswa. Jumlah keseluruhan siswa ada 73 siswa.

Hal ini terlihat ketika proses belajar berlangsung ada beberapa siswa yang tidak mempunyai motivasi untuk mengikuti proses belajar didalam kelas. Seperti sama halnya ketika guru memberikan teori yang sulit ada beberapa siswa mengeluh karena materinya sulit sehingga tidak termotivasi untuk bisa memahami materi dengan baik.

Ketika guru memberikan tugas, siswa mengeluh dengan tugas yang diberikan guru. Namun ada siswa yang lain justru bisa untuk mengikuti proses belajar dengan baik. Hal tersebut disebabkan ada beberapa siswa yang kurangnya motivasi belajar untuk mencapai prestasi belajar yang baik.

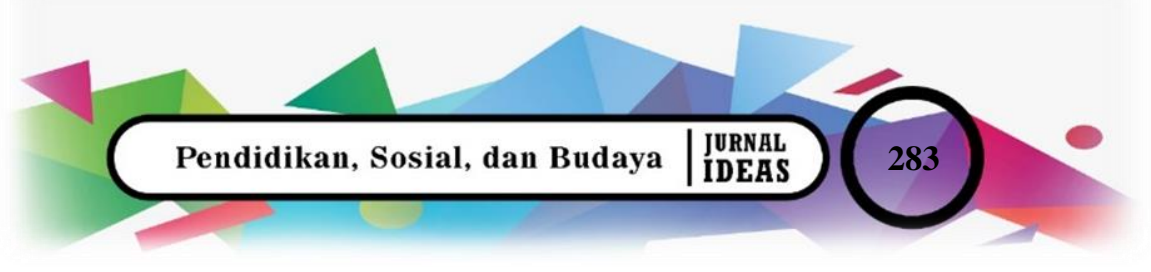




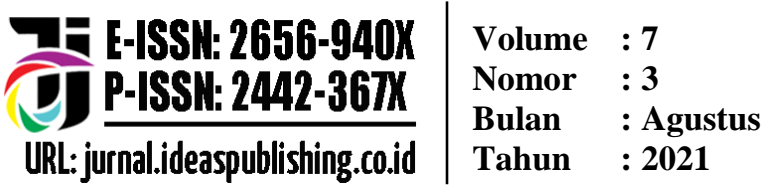

Faktor internal yang memengaruhi prestasi belajar lainnya adalah motivasi. Motivasi belajar adalah proses internal yang mengaktifkan, memandu, dan mempertahankan perilaku dari waktu ke waktu (Prayito, 1999). Individu termotivasi karena berbagai alasan yang berbeda, dengan intensitas yang berbeda. Motivasi merupakan suatu usaha yang disadari untuk menggerakkan, mengarahkan dan menjaga tingkah laku seseorang agar ia terdorong untuk bertindak melakukan Sesuatu sehingga mencapai hasil atau tujuan tertentu. Dengan adanya motivasi, siswa akan belajar lebih keras, ulet, tekun dan memiliki konsentrasi penuh dalam proses pembelajaran. Adanya motivasi yang tinggi dari dalam diri peserta didik tentunya akan memengaruhi proses pembelajaran di dalam kelas dan berpengaruh pula dengan prestasi belajar yang ingin dicapai.

Berdasarkan permasalahan yang ditemukan bahwa hasil belajar yang diperoleh siswa pada pelajaran matematika di sekolah dasar kecamatan junrejo kota batu malang menunjukkan bahwa hasil belajar tersebut belum optimal dan apabila permasalahan tersebut dibiarkan, akan berdampak buruk bagi siswa maupun sekolah. Oleh karena itu, peningkatan hasil belajar siswa harus terus di upayakan.

Prestasi belajar siswa dapat dilihat dari nilai ulangan harian, ujian tengah semester dan ujian akhir semester yang diperoleh siswa. Namun untuk mendapatkan prestasi belajar yang baik bukanlah hal yang mudah, tetapi membutuhkan usaha yang optimal. Prestasi belajar sebagai salah satu indokator hasil belajar siswa pada kenyataannya sangat ditentukan oleh beberapa faktor. Salah satu cara yang dapat digunakan untuk melihat hasil prestasi belajar dapat dilihat dari faktor-faktor yang memengaruhinya.

Merujuk pada perspektif teori belajar, beberapa faktor yang memengaruhi hasil belajar antara lain adalah lingkungan, psikologi, dan fisiologi. Secara khusus kajian ini akan mempertanyakan variabel efikasi diri dan motivasi belajar siswa dan bagaimana pengaruhnya terhadap hasil belajar siswa dengan baik.

"Self-efficacy is belief about what one is capable of doing: it is not the same as knowing what to do"'Schunk, 2012). Keyakinan atas kemampuan diri siswa memengaruhi pilihan tindakan yang akan memengaruhi pilihan tindakan yang akan dilakukan, besarnya usaha dan ketahanan ketika berhadapan dengan hambatan atau kesulitan. Efikasi diri mempunyai pengaruh yang sangat besar dalam mencapai kesuksesan atau prestasi, karena dengan adanya efikasi diri yang tinggi maka siswa akan yakin terhadap kesuksesan atau prestasi yang akan dicapai.

Tinggi rendahnya efikasi diri yang dimiliki oleh seorang siswa akan memengaruhi setiap aktivitas yang dilakukan. Siswa dengan level efikasi diri tinggi lebih mungkin untuk tekun menguasai tugas pembelajaran ketimbang siswa yang memiliki level efikasi diri rendah (Santrock, 2007). Dan selaras dengan pendapat lain yang menyatakan bahwa ketika individu memiliki kemampuan yang sama, individu yang yakin dapat melakukan suatu tugas lebih mungkin mencapai keberhasilan dibandingkan dengan individu yang tidak yakin akan sukses dalam tugas tersebut (Ormrord, 2008).

Beberapa penelitian terkait efikasi diri dan motivasi belajar telah dilakukan, antara lain penelitian dari Eka Nurinta menunjukkan bahwa terdapat pengaruh yang signifikan secara simultan antara minat belajar dan efikasi diri (Self Efficacy) siswa terhadap prestasi belajar siswa kelas VIII SMP Raden Fatah Batu pada mata pelajaran Ekonomi-IPS (Nurita, 2011). Dapat disimpulkan bahwa betapa besarnya pengaruh efikasi diri yang tinggi dapat memengaruhi hasil belajar siswa.

Adapun hasil penelitian yang dilakukan oleh Wahdania (Wahdania, 2017) menunjukkan bahwa secara bersama-sama efikasi diri, harga diri dan motivasi berpengaruh secara signifikan terhadap hasil belajar matematika peserta didik kelas X SMA Negeri 1 Bulupoddo. Koefisien determinasi sebesar 74,8\% menunjukkan bahwa 74,8\% hasil belajar matematika siswa dapat dijelaskan oleh efikasi diri, harga diri, dan motivasi peserta didik. Sehubungan dengan hal tersebut, maka dalam penelitian ini dapat dikatakan bahwa efikasi diri, harga diri, dan motivasi peserta didik memiliki jumlah pengaruh yang besar terhadap hasil belajar matematika peserta didik kelas X SMA Negeri 1 Bulupoddo Kab. Sinjai.

Penelitian yang dilakukan oleh Elis Warti (2016) dari STKIP Kusuma Negara dengan Judul "Pengaruh motivasi belajar siswa terhadap hasil belajar matematika siswa di SD Ankasa 10 Halim Perdana Kusuma Jakarta Timur" Metode penelitian ini menggunakan metode survey. Hasil penelitian menunjukkan terdapat penagruh positif dan signifikan motivasi belajar terhadap hasil belajar matematika siswa dengan koefisien kolarasi sebesar 0,974 sehingga dapat disimpulkan bahwa semain tinggi motivassi belajar siswa, maka semangkin baik perolehan hasil belajar matematika (Warti, 2016). 


$\begin{array}{ll}\text { Volume } & : 7 \\ \text { Nomor } & : \mathbf{3} \\ \text { Bulan } & : \text { Agustus } \\ \text { Tahun } & : \mathbf{2 0 2 1}\end{array}$

Penelitian yang dilakukan oleh Supran Dwi Cahyono mahasiswa dari universitas negeri Surabaya melakukan penelitian dengan judul "Pengaruh Self Efficacy terhadap hasil belajar matematika siswa kelas VIII SMP Negeri 22 Surabaya pada Materi Lingkungan". Hasil penelitian menunjukkan bahwa ada pengaruh yang signifikan antara Self Efficacy dan motivasi terhadap hasil belajar matematika siswa pada materi lingkaran dengan koefisien determinasi sebesar 19,15\% (Cahyono, 2016).

Penelitian ini berbeda dengan penelitian-penelitian sebelumnya. Peneliti melakukan kajian terhadap penelitian terdahulu yang berkenaan dengan konteks permasalahan yang dibahas pada penelitian ini. Hasil penelitian yang dilakukan oleh beberapa penelitian yang dilakukan di atas memberikan kesimpulan bahwa penelitian itu ada relevansinya dengan penelitian yang akan dilakukan, maka perbedaan dengan penelitian ini terletak pada subjek, objek, mata pelajaran dan Penelitian ini menggunakan metode penelitian kombinasi (Mixed Methods) untuk mengetahui "Pengaruh Efikasi Diri dan Motivasi Belajar Terhadap Hasil Belajar Matematika pada Siswa Sekolah Dasar di Kecamatan Junrejo Kota Batu Malang”.

Dalam proses belajar siswa sangat diperlukan adanya efikasi diri. Efikasi diri merupakan (Alwisol, 2016) keyakinan akan kemampuan diri dalam mengerjakan suatu tugas guna mencapai tujuan serta mengatasi berbagai hambatan yang ditemui. Efikasi diri adalah persepsi diri sendiri mengenai seberapa bagus diri dapat berfungsi dalam situasi tertentu. Efikasi diri berhubungan dengan keyakinan bahwa diri memiliki kemampuan melakukan tindakan yang diharapkan.

Motivasi merupakan dorongan yang terdapat dalam diri seseorang untuk berusaha mengadakan perubahan tingkah laku yang lebih baik dalam memenuhi kebutuhannya (Djali, 2017). Motivasi memegang peranan yang penting dalam proses belajar siswa. Dengan adanya motivasi, siswa akan bersemangat dan aktif dalam pembelajaran yang dilaksanakan sehingga kegiatan belajar yang dialami siswa menjadi bermakna dan hasil belajar menjadi optimal.

Efikasi diri dan motivasi belajar merupakan hal yang sangat penting dalam proses belajar. Siswa yang memiliki efikasi diri yang tinggi maka motivasi belajar juga akan tinggi dan memengaruhi hasil belajar.

Tujuan penelitian ini dilakukan untuk mencapai sesuatu yang ingin dicapai dan menjadi acuan keberhasilan penelitian. Tujuan dalam penelitian ini sebagai berikut.

1. Untuk mengetahui pengaruh efikasi diri terhadap hasil belajar matematika pada siswa sekolah dasar.

2. Untuk mengetahui pengaruh motivasi belajar terhadap hasil belajar matematika pada siswa sekolah dasar.

3. Untuk mengetahui pengaruh efikasi diri dan motivasi belajar terhadap hasil belajar matematika pada siswa sekolah dasar.

\section{Metode}

Penelitian ini menggunakan metode penelitian kombinasi (mixed methods) adalah suatu metode penelitian yang mengkombinasikan atau menggabungkan dua metode antara kuantitatif dan metode kualitatif untuk digunakan secara bersama-sama dalam suatu kegiatan penelitian sehingga diperoleh data yang lebih komprehensif, valid, realiable, dan obyektif (Sugiono, 2018).

Penelitian ini peneliti menggunakan metode penelitian kombinasi urutan penemuan analisis kuantitatif dan kualitatif (Sequantial Explanatory). Pada metode ini menggabungkan metode penelitian kuantitatif dan kualitatif secara berurutan. Pada tahap pertama penelitian dilakukan dengan metode kuantitatif untuk mengumpulkan data kuantitatif yang dapat diukur, yang bersifat deskriptif, komparatif dan asosiasif. Pada tahap kedua penelitian ini menggunakan metode kualitatif untuk membuktikan, memperdalam, memperluas, atau memperkuat data kuantitatif yang telah diperoleh pada tahap pertama (Sugiono, 2018).

Lokasi penelitian ini yaitu dilakukan di Sekolah Dasar Negeri Dadaprejo 01 Kecamatan Junrejo Kota Batu Malang dan di Sekolah Dasar Negeri Dadaprejo 02 Kecamatan Junrejo Kota Batu Malang, Provinsi Jawa Timur.

Pengumpulan data dalam penelitian ini terdiri dari dua tahapan yaitu diawali pengumpulan data secara kuantitatif dan selanjutnya pengumpulan data secara kualitatif.

1. Pengumpulan Data secara Kuantitatif

Pengumpulan data kuantitatif menggunakan angket. Angket digunakan sebagai alat pengumpul data kuantitatif. Angket digunakan sebagai alat pengumpul data dengan cara diisi oleh responden yang telah ditentukan. 


\section{Pengumpulan Data secara Kualitatif}

Pengumpulan data kualitatif dilakukan melalui wawancara, observasi dan studi dokumen. Pengumpulan data secara kualitatif dijelaskan sebagai berikut.

a. Wawancara

Wawancara digunakan sebagai alat pengumpul data kualitatif. Wawancara dilakukan oleh peneliti. Wawancara digunakan untuk mengumpulkan data tentang efikasi diri dan motivasi belajar pada siswa.

Pada penelitian ini wawancara yang digunakan adalah wawancara mendalam secara terstruktur, yaitu mengumpulkan data atau informasi dengan cara langsung bertatap muka dengan informan agar mendapatkan data yang lengkap dan mendalam. Dalam penelitian ini informannya adalah guru matematika.

b. Observasi

Observasi digunakan sebagai alat pengumpulan data kualitatif. Observasi ini dilakukan oleh peneliti sebagai observer. Observasi digunakan untuk mengumpulkan data tentang saran.

c. Studi Dokumen

Studi dokumen digunakan untuk analisis terhadap dokumen-dokumen yang digunakan sebagai data penelitian. Studi dokumen digunakan sebagai alat untuk mengumpulkan datang tentang hasil belajar matematika siswa.

Dokumen yang digunakan sebagai data penelitian yaitu dokumen penilaian hasil belajar matematika siswa. Dokumen dianalisis menggunakan lembar identifikasi dokumen. Waktu pengambilan dokumen pada saat peneliti telah melakukan wawancara dan observasi berdasarkan kesepakatan dengan masing-masing sekolah tempat penelitian.

Hasil studi dokumen diuji keabsahan data menggunakan triangulasi metode yaitu dengan cara membandingkan data hasil studi dokumen dengan data hasil wawancara, membandingkan data hasil studi dokumen dengan data hasil observasi.

Penelitian ini memakai angket terstruktur ataupun angket tertutup. Angket disebarkan pada partisipan didik sehabis pembelajaran berakhir. Angket pula terbuat dengan bahasa yang simpel serta gampang dipahami, serta mempunyai petunjuk yang jelas supaya data valid. Kuesioner ini digunakan untuk mengumpulkan data efikasi diri dan motivasi belajar.

Pernyataan ini mencakup tentang pengaruh efikasi diri dan motivasi belajar terhadap hasil belajar matematika pada siswa sekolah dasar di Kecamatan Junrejo Kota Batu Malang thn. 2020/2021 dengan alat ukur yang digunakan adalah Skala Likert. Penskoran angket juga menggunakan model skala Likert dengan alternative jawaban.

Peneliti memilih skala likert karena menurut sugiono skala likert digunakan untuk mengukur sikap, pendapat, dan persepsi seseorang atau kelompok orang tentang fenomena sosial (Sugiono, 2018).

Tabel 1

Penskoran Skala Likert

\begin{tabular}{lll}
\hline Kategori Respon & Favorable & Unfavorable \\
\hline Sangat Setuju (SS) & 4 & 1 \\
Setuju (S) & 3 & 2 \\
Tidak Setuju (TS) & 2 & 3 \\
Sangat Tidak Setuju (STS) & 1 & 4 \\
\hline
\end{tabular}

Analisis kuantitatif ini menggunakan uji normalitas, uji homogenitas dan uji regresi.

1. Analisis Deskriptif

Analisis deskriptif adalah statistik yang digunakan untuk menganalisis data dengan cara mendiskripsikan atau menggambarkan data yang telah terkumpul sebagaimana adanya tanpa maksud membuat kesimpulan yang berlaku umum atau generalisasi (Sugiono, 2018).

a. Variabel Efikasi Diri dan Motivasi Belajar

Deskripsi variabel efikasi diri diperoleh melalui dua cara (mencari nilai tertinggi dan terendah serta mencari nilai interval kelas).

1) Mencari nilai tertinggi dan terendah

Terdapat 20 item pernyataan dengan skala likert 4 pilihan maka diperoleh nilai tertinggi dan nilai terendah sebagai berikut: 
Volume : 7

Nomor : 3

Bulan : Agustus

E-ISSH: 2656-940X 간

Tahun : 2021

Nilai tertinggi $=20 \times 4=80$

Nilai terendah $=20 \times 1=20$

2) Mencari nilai interval kelas

Tabel 2

Nilai Interval Kelas Variabel Efikasi Diri

\begin{tabular}{ll}
\hline Kategori & Interval Kelas \\
\hline Sangat Tinggi & $71-80$ \\
Tinggi & $63-71$ \\
Sedang & $52-62$ \\
Rendah & $41-53$ \\
Sangat Rendah & $20-34$ \\
\hline
\end{tabular}

b. Variabel Hasil Belajar

Hasil belajar peserta didik ditentukan denagn nilai ketuntasan belajar yang siswa dapatkan. Ketuntasan belajar terbagi kedalam ketuntasan subtansi dan kurun waktu (Wahid, 2017). Acuan penilaian yang digunakan adalah penilaian acuan kriteria, artinya patokan nilai telah dibuat jauh hari sebelum tes dilakukan (Wahid, 2017). PAK ini berbeda dengan penilaian acuan norma (PAN) dimana PAN ditentukan setelah tes dilakukan.

Penilaian PAK juga sering dikenal dengan kriteria ketuntasan minimal (KKM), nilai acuan KKM ini yang nantinya akan dijadikan patokan minimal ketuntasan.

Tabel 3

Kriteria Ketuntasan Belajar

\begin{tabular}{ll}
\hline Kategori & Nilai \\
\hline Sangat Tinggi & $90-100$ \\
Tinggi & $80-89$ \\
Sedang & $70-79$ \\
Rendah & $50-69$ \\
Sangat Rendah & $0-40$ \\
\hline
\end{tabular}

\section{Hasil dan Pembahasan}

Deskripsi informasi dalam bagian ini bertujuan buat menyajikan informasi yang sudah diperoleh peneliti sehabis proses pengambilan informasi. Hasil penelitian ini diperoleh lewat analisis deskriptif dengan langkah- langlah: pertama, mengecek serta berikan nomor urut kuesioner yang sudah diisi lengkap oleh responden. Kedua, berikan skor pada item statment dalam kuesioner yang cocok dengan bobotnya.

Untuk pernyataan positif, skor itemnya merupakan 4 untuk jawaban sangat setuju (SS), skor 3 untuk jawaban setuju (S), skor 2 untuk jawaban tidak setuju (TS) dan skor 1 untuk jawaban sangat tidak setuju (STS), sedangkan untuk peryataan negatif memperoleh skor sebaliknya. Ketiga, menganalisis secara deskriptif pada variabel meliputi data mean, median, modua, standard deviation, nilai maksimal. Nilai minimal serta melaporkan dalam bentuk diagram pie. Keempat, memuat patokan pengukuran untuk kategori tingkat kecenderungan data variabel penelitin. Adapun tolak ukur kategori yang menggunakan kelas interval dengan penggolongan subjek ke dalam 5 jenis. Berikut deskripsi data:

1. Deskripsi Variabel Efikasi Diri $\left(\mathrm{X}_{1}\right)$

Variabel bebas yang pertama dalam penelitian ini adalah efikasi diri. Instrumen yang digunakan dalam penelitian ini adalah kuesioner dengan jumlah 20 butir pernyataan. Analisis deskripsi jawaban siswa tentang variabel efikasi diri $\left(\mathrm{X}_{1}\right)$ didasarkan pada jawaban siswa atas pernyataan-pernyataan yang terdapat dalam kuesioner yang disebar.

Data deskripsi yang ditampilkan pada tabel 1 merupakan data efikasi diri siswa SDN Dadaprejo 01 dan SDN Dadaprejo 02 kota batu malang. Berikut adalah analisis variabel efikasi diri.

Tabel 4

Analisis Deskripsi Variabel Efikasi Diri (X1)

\begin{tabular}{lll}
\hline & N & Total \\
\hline Mean & 73 & 60.41 \\
Median & 73 & 60.00 \\
Modus & 73 & 80 \\
Std. Deviation & 73 & 10.947 \\
Minimum & 73 & 36 \\
Maximum & 73 & 80
\end{tabular}


Berdasarkan tebel di atas untuk efikasi diri diperoleh mean=60,41, median 60,00, modus=80, skor minimal=36, dan skor maksimal=80. Berdasarkan data tersebut dapat disimpulkan bahwa efikasi diri siswa kelas V disekolah dasar negeri Dadaprejo 01 Junrejo dan di sekolah dasar negeri Dadaprejo 02 Junrejo kota batu malang dapat dikategorikan sedang dan tinggi.

Deskripsi variabel efikasi diri diri siswa kelas V disekolah dasar negeri Dadaprejo 01 dan disekolah dasar negeri dadaprejo 02 Junrejo kota batu malang yang menjadi responden penelitian dapat dilihat pada tabel 5 berikut ini:

Tabel 5

Perhitungan Interval Efikasi Diri (X1)

\begin{tabular}{lllll}
\hline No & Kriteria & Interval & Frekuensi & Persentase \\
\hline 1 & Sangat Tinggi & $64-80$ & 30 & $41 \%$ \\
2 & Tinggi & $55-63$ & 17 & $23 \%$ \\
3 & Sedang & $46-54$ & 21 & $29 \%$ \\
4 & Rendah & $37-45$ & 4 & $6 \%$ \\
5 & Sangat Rendah & $20-36$ & 1 & $1 \%$ \\
\hline & Jumlah & & 73 & $100 \%$ \\
\hline
\end{tabular}

Berdasarkan dari tabel di atas dapat diketahui bahawa 30 responden atau $41 \%$ memiliki efikasi yang sangat tinggi dalam belajar, 17 responden atau 23\% memiliki efikasi diri tinggi dalam belajar, 21 responden atau $29 \%$ memiliki efikasi diri sedang dalam belajar, 4 responden atau $6 \%$ memiliki efikasi diri rendah dalam belajar dan 1 reponden atau $1 \%$ memiliki efikasi diri yang sangat rendah dalam belajar.

2. Deskripsi Variabel Motivasi Belajar $\left(\mathrm{X}_{2}\right)$

Analisis deskripsi jawaban siswa tentang variabel motivasi belajar $\left(\mathrm{X}_{2}\right)$ didasarkan pada jawaban siswa atas pernyataan-pernyataan yang terdapat dalam kuesioner yang disebar.

Data deskripsi yang ditampilkan merupakan data motivasi belajar siswa SDN 01 dan SDN 02 kota batu malang. Berikut adalah analisis variabel motivasi belajar.

Tabel 6

Analisis Deskripsi Variabel Motivasi Belajar (X2)

\begin{tabular}{lll}
\hline & N & Total \\
\hline Mean & 73 & 60.93 \\
Median & 73 & 61.00 \\
Modus & 73 & 67 \\
Std. Deviation & 73 & 10.407 \\
Minimum & 73 & 36 \\
Maximum & 73 & 80 \\
\hline
\end{tabular}

Berdasarkan tabel 6 di atas untuk motivasi belajar diperoleh mean=60,93, median 61,00, modus=67, skor minimal $=36$, dan skor maksimal=80. Berdasarkan data tersebut dapat disimpulkan bahwa motivasi belajar siswa kelas $\mathrm{V}$ disekolah dasar 01 dan disekolah 02 Junrejo kota batu malang dapat dikategorikan sedang dan tinggi.

Deskripsi variabel motivasi belajar diri siswa kelas V disekolah dasar 01 dan disekolah 02 Junrejo kota batu malang yang menjadi responden penelitian dapat dilihat pada tabel berikut ini:

Tabel 7

Perhitungan Interval Motivasi Belajar (X2)

\begin{tabular}{lllll}
\hline No & Kriteria & Interval & Frekuensi & Persentase \\
\hline 1 & Sangat Tinggi & $64-80$ & 30 & $41 \%$ \\
2 & Tinggi & $55-63$ & 22 & $30 \%$ \\
3 & Sedang & $46-54$ & 17 & $23 \%$ \\
4 & Rendah & $37-45$ & 3 & $4 \%$ \\
5 & Sangat Rendah & $20-36$ & 1 & $2 \%$ \\
\hline
\end{tabular}

Berdasarkan tabel 7 di atas dapat diketahui bahawa 30 responden atau $41 \%$ memiliki motivasi belajar yang sangat tinggi dalam belajar, 22 responden atau 30\% memiliki motivasi belajar yang tinggi dalam belajar, 17 responden atau 23\% memiliki motivasi belajar yang sedang dalam belajar, 3 responden atau $4 \%$ memiliki motivasi belajar yang rendah dalam belajar dan 1 reponden atau $2 \%$ memiliki motivasi belajar yang sangat rendah dalam belajar. 
$\begin{array}{ll}\text { Volume } & : 7 \\ \text { Nomor } & : 3 \\ \text { Bulan } & : \text { Agustus } \\ \text { Tahun } & : 2021\end{array}$
E-ISSH: 2656-940X P-ISSH: 2442-367K

URL: jurnal.ideaspublishing.co.id

3. Deskripsi Variabel Hasil Belajar Matematika (Y)

Analisis deskripsi variabel (Y) dalam penelitian ini adalah hasil belajar matematika. Untuk mengukur variabel ini, peneliti menggunakan data sekunder berupa nilai siswa pada ujian akhir semester. Hasil penilaian akhir semester yang digunakan merupakan nilai rata-rata dari hasil nilai matematika yang didapatkan oleh peserta didik.

Jika dilihat dari nilai rata-rata yang didapat peserta didik, maka nilai tersebut mencerminkan bahwa banyaknya peserta didik yang mencapau nilai Kriteria Ketuntasan Minimal (KKM) dimana nilai KKM yang ditentukan adalah 70. Artinya jika peserta didik dapat mencapai nilai 70 maka peserta didik dianggap lulus. Berikut statistik data hasil belajar siswa di SDN Dadaprejo 01 dan SDN Dadaprejo 02 dapat dilihat pada tabel 8 berikut:

Tabel 8

Nilai Ujian Akhir Semester Matematika Siswa

\begin{tabular}{lll}
\hline No & Nilai & Frekuensi \\
\hline 1 & 55 & 3 \\
2 & 60 & 7 \\
3 & 70 & 9 \\
4 & 75 & 4 \\
5 & 80 & 23 \\
6 & 85 & 4 \\
7 & 90 & 9 \\
8 & 95 & 2 \\
9 & 100 & 12 \\
\hline Jumlah & & 73 \\
\hline
\end{tabular}

Berdasarkan tabel 8 di atas bahwa siswa Kelas V SDN Dadaprejo 01 dan SDN Dadaprejo 02 diketahui bahwa nilai tertinggi dengan total 12 siswa. Selanjutnya untuk nilai yang rendah dengan total 3 siswa.

Pengelompokkan variabel hasil belajar matematika menurut kategori didasarkan pada kriteria rentang: sangat tinggi, tinggi, sedang, rendah, sangat rendah. Deskripsi variabel hasil belajar siswa di SDN Dadaprejo 01 dan SDN Dadaprejo 02 dapat dilihat pada tabel 9 berikut:

Tabel 9

Perhitungan dan Distribusi Frekuensi Variabel Hasil Belajar (Y)

\begin{tabular}{llll}
\hline Skor & Frekuensi & Persentase & Interprestasi \\
\hline $90-100$ & 23 & $31 \%$ & Sangat Tinggi \\
$80-89$ & 27 & $37 \%$ & Tinggi \\
$70-79$ & 13 & $18 \%$ & Sedang \\
$50-69$ & 10 & $14 \%$ & Rendah \\
$0-49$ & 0 & $0 \%$ & Sangat Rendah \\
\hline Total & 73 & 100 & \\
\hline
\end{tabular}

Berdasarkan tabel 9 di atas dapat diketahui bahwa 23 responden atau 31\% memiliki hasil belajar matematika yang sangat tinggi, 27 responden atau 37\% memiliki hasil belajar matematika yang tinggi, 13 responden atau $18 \%$ memiliki hasil belajar matematika yang sedang, 10 responden atau $14 \%$ memiliki hasil belajar matematika yang rendah.

Tabel 10

Analisis Deskripsi Variabel Hasil Belajar (Y)

\begin{tabular}{lll}
\hline & N & Total \\
\hline Mean & 73 & 80.75 \\
Median & 73 & 80.00 \\
Modus & 73 & 80 \\
Std. Deviation & 73 & 12.847 \\
Minimum & 73 & 55 \\
Maximum & 73 & 100 \\
\hline
\end{tabular}

Berdasarkan dari tabel 10 di atas untuk hasil belajar matematika diperoleh mean=80,75, median 80, modus $=80$, skor minimal $=55$, dan skor maksimal=100. Berdasarkan data tersebut dapat disimpulkan bahwa hasil belajar matematika siswa kelas V disekolah dasar dadaprejo 01 dan disekolah dadaprejo 02 Junrejo

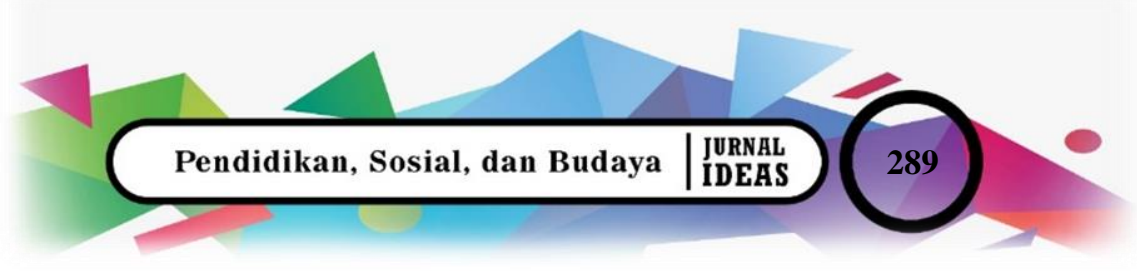


kota batu malang dapat dikategorikan sedang dan tinggi. Distribusi frekuensi hasil belajar matematika dapat ditampilkan dalam diagram pie berikut:

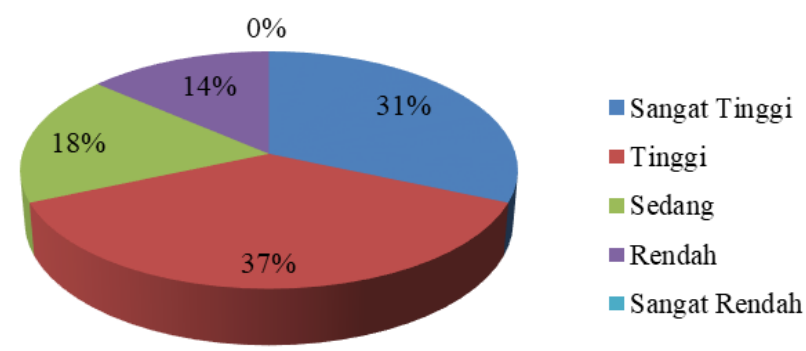

Gambar 1 Diagram Lingkaran Hasil Belajar Matematika (Y)

Berdasarkan dari gambar 1 di atas dapat disimpulkam bahwa nilai rata-rata hasil belajar siswa hanya terdapat $31 \%$ siswa yang dapat mencapai nilai Kriteria Ketuntasan Minimal (KKM).

\section{Pengaruh Efikasi Diri terhadap Hasil Belajar Matematika pada Siswa Sekolah Dasar}

Melalui kuesioner yang telah disebar oleh peneliti kepada siswa diperoleh data yang kemudian diolah menggunakan aplikasi SPSS Versi 23 didapat bahwa $t_{\text {hitung }}<t_{\text {tabel }}(3,067>1,997)$ dengan signifikan $0,003<0,05$ Yang artinya variabel efikasi diri secara parsial berpengaruh dan signifikan terhadap hasil belajar sehingga $\mathrm{H}_{\mathrm{a}}$ diterima dan $\mathrm{H}_{0}$ ditolak.

Penemuan di atas sejalan dengan Bandura (1997) mendefinisikan konsep efikasi diri selaku kepercayaan tentang keahlian yang dipunyai buat mengendalikan serta melaksanakan serangkaian aksi yang dibutuhkan dalam menggapai keinginannya. Semangkin besar efikasi diri yang dipunyai oleh seorang hingga hendak terus menjadi besar pula kepercayaan atas kemampuannya sendiri kalau dia sanggup menggapai tujuannya dengan kerja kerasnya. Seorang yang mempunyai efikasi diri besar hendak berupaya melaksanakan tugasnya yang dia persepsikan bisa dilaksanakannya serta dia hendak menjauhi suasana serta sikap yang ia persepsikan diluar batasan kemampuannya, gigih dalam berupaya menggapai tujuan serta bisa merasa percaya terhadap keahlian dirinya.

Berdasarkan hasil penelitian ini, siswa yang memiliki efikasi diri tinggi akan menghasilkan hasil belajar yang tinggi pula. Siswa yang memiliki efikasi diri yang tinggi yaitu siswa yang mempunyai keyakinan dan kegigihan untuk menyelesaikan soal yang sulit dan bahkan sebaliknya. Siswa yang memiliki efikasi diri rendah maka hasil belajar siswa juga akan rendah. Bahkan siswa akan mudah putus asa dan mudah menyerah jika menghadapi rintangan akan kesulitan. Keyakinan diri yang tinggi juga akan membawa siswa merasa puas dengan kemampuannya ketika dapat mengerjakan soal yang sulit. Semakin seringnya siswa melewati dan mencoba mengerjakan soal yang sulit akan semakin terlatih dan mampu menghadapi soal-soal ujian dengan tenang dan percaya diri sehingga mendapat nilai yang baik dan tuntas sesuai yang diharapkan oleh sekolah atau guru mata pelajaran matematika.

\section{Pengaruh Motivasi Belajar terhadap Hasil Belajar Matematika pada Siswa Sekolah Dasar}

Melalui kuesioner yang telah disebar oleh peneliti kepada siswa diperoleh data yang kemudian diolah menggunakan aplikasi SPSS Versi 23 didapat bahwa $t_{\text {hitung }}>t_{\text {tabel }}(3.847>1,997)$ dengan signifikansi $0,000<$ 0,05 yang mana artinya variabel motivasi belajar secara parsial berpengaruh dan signifikan terhadap hasil belajar matematika sehingga $\mathrm{H}_{\mathrm{a}}$ diterima dan $\mathrm{H}_{0}$ ditolak. Dengan adanya motivasi, maka siswa akan didorong untuk belajar mencapai sasaran dan tujuan karena yakin dan sadar akan kebaikan tentang kepentingan dan manfaatnya dari belajar. Bagi siswa, motivasi itu sangat penting karena dapat menggerakkan perilaku siswa kearah yang positif sehingga mampu menghadapi segala tuntutan, kesulitan serta mampu menanggung resiko dalam studinya. Menurut Dalyono (1997) motivasi dapat menentukan baik tidaknya dalam mencapai tujuan sehingga semakin besar motivasinya akan semakin besar kesuksesan belajarnya.

Mengingat pentinganya motivasi belajar dalam hal memengaruhi hasil belajar. Dalam penelitian ini sejalan dengan penelitian yang dilakukan oleh Ilyas (2014) yang menemukan terdapat pengaruh positif dan signifikan motivasi belajar terhadap hasil belajar. Hal ini menunjukkan bahwa hasil belajar mampu dijelaskan oleh motivasi belajar. Semakin tinggi motivasi belajar yang ditujukan dengan adanya kemauan untuk giat belajar 


$\begin{array}{ll}\text { Volume } & : 7 \\ \text { Nomor } & : \mathbf{3} \\ \text { Bulan } & : \text { Agustus } \\ \text { Tahun } & : \mathbf{2 0 2 1}\end{array}$

E-ISSH: 2656-940X 글 P-ISSH: 2442-367K Dि URL:jurnal.ideaspublishing.co.id

serta kerja keras guna mencapai hasil belajar yang baik dan memuaskan maka hasil belajar yang diperoleh siswa akan semakin tinggi.

\section{Pengaruh Efikasi Diri dan Motivasi Belajar terhadap Hasil Belajar Matematika pada Siswa Sekolah Dasar}

Melalui kuesioner yang telah disebar oleh peneliti kepada siswa diperoleh data yang kemudian diolah menggunakan aplikasi SPSS Versi 23 didapat bahwa nilai $\mathrm{F}_{\text {hitung }} 8,572>\mathrm{F}_{\text {tabel }} 3,15$ dan dengan tingkat signifikan sebesar $0,000<0,05$ maka dapat disimpulkan bahwa $\mathrm{H}_{\mathrm{a}}$ diterima dan $\mathrm{H}_{0}$ ditolak. Jadi, dapat diartikan bahwa variabel efikasi diri dan motivasi belajar secara simultan berpengaruh dan signifikan terhadap hasil belajar matematika siswa.

Dari hasil analisis koefisien determinasi (R Square) adalah sebesar 0,197 yang berarti variabel efikasi diri $\left(\mathrm{X}_{1}\right)$ dan variabel motivasi belajar $\left(\mathrm{X}_{2}\right)$ secara simultan berpengaruh terhadap variabel hasil belajar matematika (Y) sebesar $19,7 \%$. Sedangkan sisanya sebesar $80,3 \%$ dijelaskan oleh faktor-faktor lain yang tidak disertakan dalam penelitian ini.

Dalam penelitian ini secara bersama-sama atau secara simultan variabel efikasi diri dan motivasi belajar memengaruhi hasil belajar matematika.

\section{Simpulan}

Berdasarkan hasil penelitian dan analisis secara langsung menyebar kuesioner/angket serta melakukan wawancara kepada responden, yang dipilih secara keseluruhan untuk pengeumpulan data kuantitatif dan menggunakan simple random sampling untuk pengumpulan data kualitatif dengan responden SDN Dadaprejo 01 dan SDN Dadaprejo 02 Kota Batu, diperoleh kesimpulan sebagai berikut.

1. Pengaruh efikasi diri terhadap hasil belajar matematika pada siswa sekolah dasar didapat bahwa $t_{\text {hitung }}<t_{\text {tabel }}$ $(3,067>1,997)$ dengan signifikan $0,003<0,05$ Yang artinya variabel efikasi diri secara parsial berpengaruh dan signifikan terhadap hasil belajar sehingga $\mathrm{H}_{\mathrm{a}}$ diterima dan $\mathrm{H}_{0}$ ditolak.

2. Pengaruh motivasi belajar terhadap hasil belajar matematika pada siswa sekolah dasar didapat bahwa $t_{\text {hitung }}$ $>\mathrm{t}_{\text {tabel }}(3.847>1,997)$ dengan signifikansi $0,000<0,05$ yang mana artinya variabel motivasi belajar secara parsial berpengaruh dan signifikan terhadap hasil belajar matematika sehingga $\mathrm{H}_{\mathrm{a}}$ diterima dan $\mathrm{H}_{0}$ ditolak.

3. Pengaruh efikasi diri motivasi belajar terhadap hasil belajar matematika pada siswa sekolah dasar didapat bahwa nilai $F_{\text {hitung }} 8,572>F_{\text {tabel }} 3,15$ dan dengan tingkat signifikan sebesar 0,000<0,05 maka dapat disimpulkan bahwa $\mathrm{H}_{\mathrm{a}}$ diterima dan $\mathrm{H}_{0}$ ditolak. Jadi, dapat diartikan bahwa variabel efikasi diri dan motivasi belajar secara simultan berpengaruh dan signifikan terhadap hasil belajar matematika siswa.

\section{Daftar Rujukan}

Ahmad, S. (2013). Teori Belajar dan Pembelajaran di Sekolah Dasar. Kencana Prenada Group.

Alwisol. (2016). Psikologi Kepribadian. Universitas Muhammadiyah Malang Press.

Cahyono, D. (2016). "Pengaruh Self Efficacy terhadap hasil belajar matematika siswa kelas VIII SMP Negeri 22 Surabaya pada Materi Lingkungan". universitas negeri Surabaya.

Djali. (2017). Psikologi Pendidikan. PT Bumi Aksara.

Nurita, E. (2011). Pengaruh Minat Belajar dan Efikasi Diri (Self Efficacy) terhadap Prestasi Belajar Siswa pada Mata Pelajaran Ekonomi-IPS Kelas VIII SMP Raden Fatah Baru [Universitas Malang]. http://mulok.library.um.ac.id/index3.php/52095.html

Ormrord. (2008). Psikologi Pendidikan. Erlangga.

Prayito, E. (1999). Morivasi dalam Belajar. p12, PTK.

Santrock. (2007). Psikologi Pendidikan. Salemba Humanika.

Schunk. (2012). Teori-teori pembelajaran perspektif pendidikan edisi enam. Pustaka Pelajar.

Sugiono. (2018). Metode penelitian Kombinasi (Mixed Methods). Alfabeta.

Waarti, E. (2016). Pengaruh motivasi belajar siswa terhadap hasil belajar matematika siswa di SD Ankasa 10 Halim Perdana Kusuma Jakarta Timur. STKIP Kusuma Negara.

Wahdania. (2017). Pengaruh Efikasi Diri, Harga Diri dan Motivasi Terhadap Hasil Belajar Matematika Peserta Didik Kelas X SMA Negeri 1 Bulupoddo Kab. Sinjai.

Wahid, M. (2017). Metodologi Pembelajaran IPS. Ar-Ruzz Media. 
Volume : 7

Nomor : 3

URL: jurnal.ideaspublishing.co.id

Bulan : Agustus

Tahun : 2021 